J. Clin. Chem. Clin. Biochem.

Vol. 27. 1989. pp. 555-565

(C) 1989 Walter de Gruyter \& Co. Berlin - New York

\title{
The Role of Thrombocytes in Liver Fibrogenesis: Effects of Platelet Lysate and Thrombocyte-Derived Growth Factors on the Mitogenic Activity and Glycosaminoglycan Synthesis of Cultured Rat Liver Fat Storing Cells
}

\author{
By $M . G$ Bachem, R. Melchior and A. M. Gressner \\ Abteilung für Klinische Chemie und Zentrallaboratorium, Philipps Universität Marburg, Federal Republic of \\ Germany
}

(Received April 17/July 18, 1989)

Summary: A central problem in the study of the pathogenesis of liver fibrosis (fibrogenesis) is the identification of the cellular sources of the extracellular matrix and the dissection of the molecular mediators stimulating connective tissue synthesis in certain hepatic target cells. In the present study the role of platelets and of some platelet-derived polypeptide growth factors in the proliferation and proteoglycan synthesis of rat liver fat storing cells in culture (the principle connective tissue-producing cell type in liver) was determined. Fat storing cell proliferation was determined by measurement of the DNA-content, and $\left[{ }^{3} \mathrm{H}\right]$ thymidine- and bromodeoxyuridine-incorporation. Glycosaminoglycan synthesis was determined by the measurement of ${ }^{35}$ S $]$ sulphate incorporation.

Human platelet lysate ( 0.3 to $2.6 \mathrm{~g}$ protein per litre medium) stimulated, in a dose-dependent manner, both the proliferation and glycosaminoglycan synthesis of rat liver fat storing cells kept as a primary culture in Dulbecco's modification of Eagle's medium in the absence of foetal calf serum. More than $70 \%$ of the newly synthesized glycosaminoglycans were found in the medium. Among the various thrombocyte-derived polypeptides tested as candidate mediators of the platelet-derived fibrogenic activity, platelet derived growth factor was not effective in enhancing glycosaminoglycan synthesis, and it stimulated the proliferation of fat storing cells only about 2 fold. On the other hand, epidermal growth factor proved to be a stimulus of both processes. Transforming growth factor $\beta$ (> $10 \mathrm{pmol} / \mathrm{l}$ ) inhibited foetal calf serum (Dulbecco's modification of Eagle's medium with a fraction of foetal calf serum of 0.1 ) and epidermal growth factor stimulated proliferation but enhanced the synthesis of sulphated glycosaminoglycans about 2-fold. These results suggest the possible role of transforming growth factor $\beta$ as a negative modulator for fat storing cells proliferation but a positive modulator for fät storing cell transformation and extracellular glycosaminoglycan matrix synthesis. Furthermore, our results indicate a cooperation between different hepatic and extrahepatic cell types by paracrine stimulation of fat storing cells. Transforming growth factor $\beta$ in combination with epidermal growth factor appear to be candidate mediators of the platelet=derived fibrogenic activity, which stimulates fat storing cells in culture, and might also be effective in vivo during hepatic repair processes following liver injury.

\section{Introduction}

Persistent liver cell injury, irrespective of its aetiology, may be followed by liver fibrosis; which is defined by

(i) an excess and irregular deposition of connective tissue elements in the intercellular space, (ii) a molecular rearrangement of connective tissue composition, and

(iii) modifications of the fine structure of the various connective tissue molecules (1). 
The main components of human and animal liver extracellular matrix are several types of collagens $(2-5)$, some structural glycoproteins (fibronectin, laminin) (6), a group of proteoglycans (proteoheparan sulphate, proteochondroitin sulphate, proteodermatan (sulphate) $(1,7-9)$, the glycosaminoglycan, hyaluronic acid $(7,10)$, and elastin. In fibrotic liver the concentration of all extracellular matrix elements, except heparan sulphate, is elevated several-fold. The cells responsible for producing the various connective tissue components are hepatocytes, which synthesize predominantly heparan sulphate, as well as fibronectin, laminin (6) and potentially some collagens $(2,3)$ and certain non-parenchymal liver cells (fat storing cells, endothelial cells), which produce several extracellular matrix components. Liver fat storing cells attract increasing interest, because under certain conditions fat storing cells proliferate strongly $(4,9,11$, 12) and transform into myofibroblast like cells (13). These stain positively for the cytoskeletal protein, desmin (14), and they produce significant quantities of connective tissue components and, interestingly, a pattern of glycosaminoglycans and collagen similar to that found in fibrotic liver extracellular matrix (1, $4,5,7,8,15,16)$. These reactions are considered to be important events in human and animal liver fibrogenesis $(1,5,7,10,16-18)$. So far, little is known about the factors (fibrogenic mediators) which promote proliferation/transformation and extracellular matrix synthesis of fat storing cells. Recently, studies from others and from our laboratory have shown that secretions of activated Kupffer cells and monocytes stimulated the proliferation/transformation of fat storing cells in culture $(9,12)$, as well as stimulating the synthesis of proteoglycans (16) and hyaluronic acid (10) by these cells. Activated macrophages produce platelet derived growth factor, transforming growth factor $\alpha$ (19) and transforming growth factor $\beta$, all of which may be candidate mediators of macrophage-derived fibrogenic actitiviy. The findings that

(i) an enhanced pool of platelets together with infiltrated inflammatory cells are seen by electron microscopy in liver cell necrotic areas (20),

(ii) platelets are the richest source of transforming growth factor $\beta 1(21,22)$, and

(iii) platelet derived growth factor and the transforming growth factor $\alpha$-like epidermal growth factor may be released from alpha granules of platelets following platelet activation (23), support the hypothesis that thrombocytes might be involved in liver fibrogenesis by stimulating the growth, transformation and extracellular matrix synthesis of fat storing cells.
The purpose of this study was to isolate and cultivate rat liver fat storing cells, in order to study the stimulatory potency of human thrombocyte lysate and of platelet derived growth factor, epidermal growth factor and transforming growth factor $\beta$ on fat storing cell proliferation/transformation and on glycosaminoglycan synthesis. Our results indicate that

(i) thrombocytes stimulate fat storing cell proliferation and the synthesis and secretion of sulphated glycosaminoglycans by these cells,

(ii) transforming growth factor $\beta$ and epidermal growth factor are probably effector molecules of platelet-derived fibrogenic activity.

\section{Materials and Methods}

Materials

Thrombocyte concentrate was isolated by centrifugation at $300 \mathrm{~g}$ (1500 $\mathrm{min}^{-1}$ ) (Fenwal CS-3000 cell separator) from normal human donor blood. Human epidermal growth factor ( $\beta$ urogastrone), collagenase $\mathrm{H}$ (clostridiopeptidase $\mathrm{A}$, EC 3.4.24.3) and foetal calf serum were from Boehringer Mannheim, FRG. Transforming growth factor $\beta$ (source human platelets) was purchased from ICN Biochemicals, Cleveland, Ohio, USA. Monoclonal mouse antibodies to BrdUrd and nuclease were from Amersham Buchler, Braunschweig, FRG. $\left[{ }^{3} \mathrm{H}\right]$ thymidine $(673 \mathrm{TBq} / \mathrm{mol})$ and $\left[{ }^{35} \mathrm{~S}\right]$ sulphate $(18.5-22.2$ $\mathrm{TBq} / \mathrm{mol}$ ) were from New England Nuclear Corp., Boston, Mass. USA and Nycodenz (analytical grade) was from Nyegaard and Co. AS, Oslo, Norway. Calf thymus DNA (type I), pronase and platelet derived growth factor (source human platelets) were from Sigma Chemical Company, Munich, FRG. Peroxidase-conjugated rabbit-anti-mouse-immunoglobulins and antibodies to desmin and vimentin were purchased from Dakopatts, Glostrup, Denmark.

\section{Preparation of thrombocyte lysate}

Human thrombocyte concentrate (kindly supplied by Prof. Kretschmer, Abt. f. Transfusionsmedizin, Universitätsklinik Marburg) was lysed by sonification, centrifuged at $4{ }^{\circ} \mathrm{C}$ for 20 $\mathrm{min}$ at $3000 \mathrm{~g}$ and the supernatant was dialysed extensively (cut off $M_{\mathrm{r}} 3500$ ) against Dulbecco's modification of Eagle's medium at $4{ }^{\circ} \mathrm{C}$.

\section{Cell isolation and cell culture}

Detailed procedures for the isolation and culture of fat storing cells from rats have been published previously from this labo= ratory $(7-9,16)$. Briefly, the cells were isolated from one year old, 500-650 g male Sprague Dawley rats (Lippische Versuchstierzucht, Extertal, FRG). Non-parenchymal cells were isolated by the pronase/collagenase method of de Leeuw et al. (4), as originally described by Knook et al. (24), with some minor modifications described in detail elsewhere (8). They were purified by a single-step Nycodenz density gradient $(82 \mathrm{~g} / \mathrm{l})$. The cells were seeded at a density of $0.2-0.4 \times 10^{6}$ cells $/ 2 \mathrm{~cm}^{2}$ on 24-well culture plates (Greiner, Nürtingen, FRG), or at a density of $0.4 \times 10^{6}$ cells $/ 10 \mathrm{~cm}^{2}$ on 6-well culture plates (Greiner, Nürtingen, FRG); or at a density of 0.04-0.1 $\times 10^{6} \mathrm{cells} / \mathrm{cm}^{2}$ on $1 \mathrm{~cm}^{2}$ glass cover slips. They were then grown in Dulbecco's modification of Eagle's medium (Flow Laboratories GmbH, Bonn, FRG) with $4 \mathrm{mmol} / 1 \mathrm{~L}$-glutamine, $100 \mathrm{kU} / 1$ penicillin, 


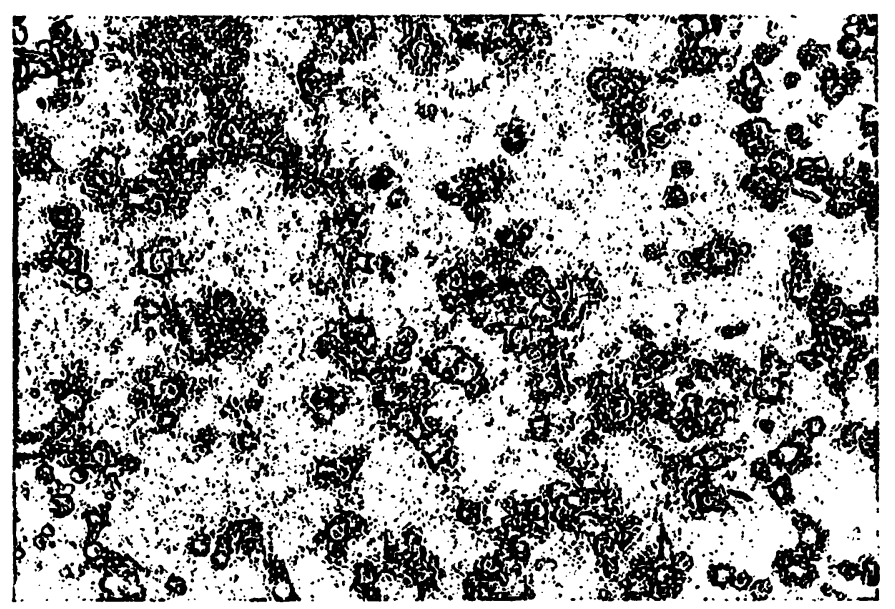

a)

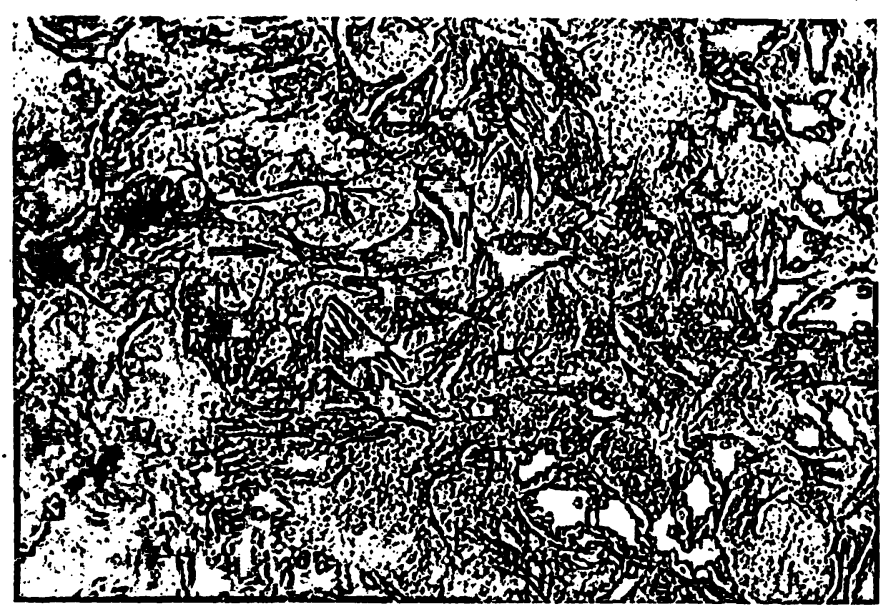

d)

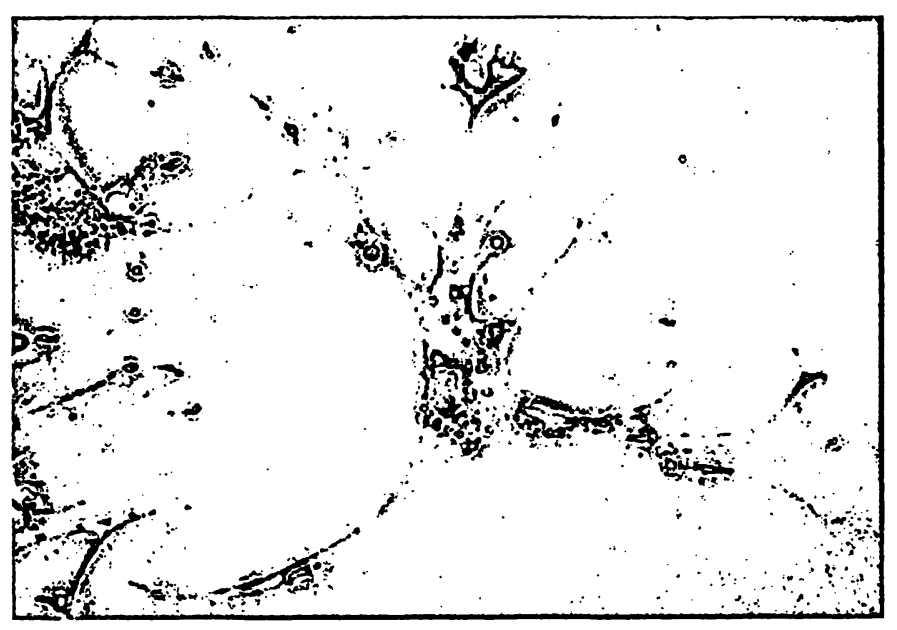

b)

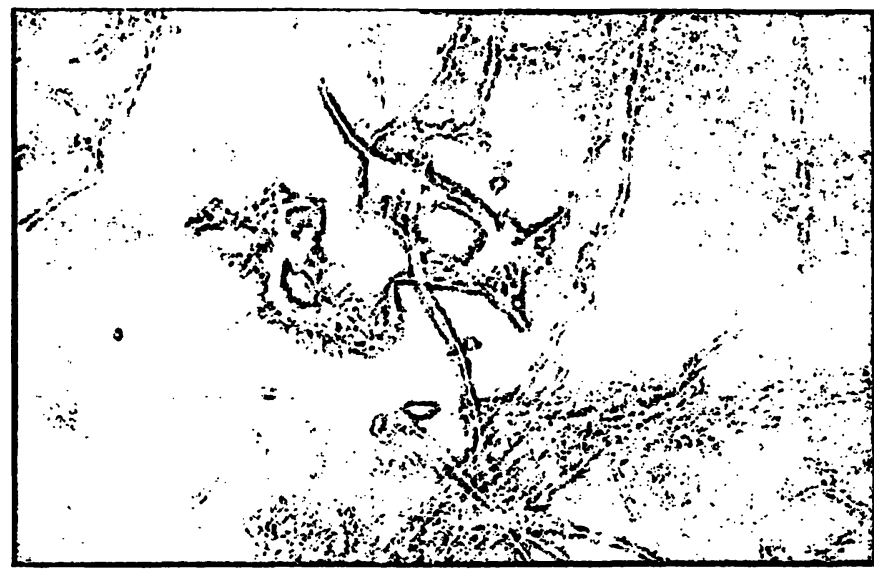

e)

Fig. 1. Microscopy of rat liver fat storing cells in primary culture.

a) Light microscopy $18 \mathrm{~h}$ after seeding (before 2nd medium change). Seeding density was $0.02 \times 10^{6}$ cells $/ \mathrm{cm}^{2}$. Fat storing cells show numerous lipid droplets arround the nucleus. Magnification $75 \times$.

b) Phase contrast microscopy of a single fat storing cell on the 5th day of culture. The cell is flat and shows long cellular extensions and residues of cytoplasmic lipid droplets. Magnification $175 \times$.

c) Indirect immunoperoxidase staining for desmin. Primary culture of fat storing cells grown in Dulbecco's modification of Eagle's medium containing a fraction of 0.1 foetal calf serum 8 days after seeding. About $70 \%$ of the cells are stained. Examples of desminnegative cells are indicated by an arrow. Seeding density was $0.02 \times 10^{6}$ cells $/ \mathrm{cm}^{2}$. Magnification $75 \times$.

d) Phase contrast microscopy of the same cells as in fig. 1c. Examples of desmin-negative cells are indicated by an arrow. Magnification $75 \times$.

e) Indirect immunofluorescence staining for vimentin. Primary culture of fat storing cells grown in Dulbecco's modification of Eagle's medium with a fraction of 0.1 foetal calf serum 6 days after seeding. Many fibrils of vimentin are recognized in the cytoplasm. Magnification $160 \times$. 
$100 \mathrm{mg} / \mathrm{l}$ streptomycin and a fraction of 0.1 foetal calf serum in a humidified atmosphere of $0.05 \mathrm{CO}_{2}$ and 0.95 air at $37^{\circ} \mathrm{C}$. The purity of the fat storing cell preparations was assessed by light-microscopy (fig. 1a), using the presence of perinuclear lipid droplets and the typical cell shape as markers, and by vitamin A-specific autofluorescence (8). At a later stage of the culture, purity was assessed by phase contrast microscopy (fig. 1b) and by immunofluorescence/immunoperoxidase staining for desmin (fig. 1c) and vimentin (fig. 1d). The mean purity of freshly isolated cells was greater than $85 \%$, and cell viability assessed by trypan blue exclusion was more than $80 \%$. With the first (about $8 \mathrm{~h}$ after seeding) and second (about $20 \mathrm{~h}$ after seeding) medium change, most of the contaminating cells were removed, and the fat storing cell monolayers were essentially free from impurities. With the third medium change (about $44 \mathrm{~h}$ after seeding) foetal calf serum in Dulbecco's modification of Eagle's medium was omitted and thrombocyte lysate (5-40 $\mu \mathrm{l}=0.325-2.6 \mathrm{mg}$ protein) was added. In experiments to study the effects of platelet-derived growth factors, the fractional content of foetal calf serum was decreased to 0.005 at the third medium change, and test substances [platelet derived growth factor $(0.25-5 \mu \mathrm{g} / \mathrm{l})$, epidermal growth factor $(5-50$ $\mu \mathrm{g} / \mathrm{l})$, and transforming growth factor $\beta(0.025-6 \mu \mathrm{g} / \mathrm{l})]$ were added. Twenty four hours later, the medium was changed in order to introduce radiolabelled precursors, and this new medium also contained fresh supplements of growth factors.

\section{Determination of cell proliferation}

\section{DNA measurement}

The DNA content of the fat storing cell monolayer ( 4 days after seeding) was measured fluorometrically using calf thymus DNA (type I, Sigma Chem. Co., Munich, FRG) as a standard (25).

\section{$\left.{ }^{3} H\right]$ Thymidine incorporation}

Thymidine incorporation was measured after trichloroacetic acid precipitation of cells, which had been exposed for $24 \mathrm{~h}$ to $\left[{ }^{3} \mathrm{H}\right]$ thymidine (74 MBq/l medium), beginning on the third day after seeding (9).

\section{Bromodeoxyuridine incorporation}

To study BrdUrd incorporation, fat storing cells were seeded at a density of $0.04-0.1 \times 10^{6}$ cells $/ \mathrm{cm}^{2}$ in Dulbecco's modification of Eagle's medium containing a fraction of 0.1 foetal calf serum on $1 \mathrm{~cm}^{2}$ glass cover slips in 6 well $(3 \mathrm{ml} /$ well) macroplates (Greiner, Nürtingen, FRG). Twenty four h after seeding, foetal calf serum was decreased to $5 \mathrm{ml} / \mathrm{l}$ medium, and growth factors were added. Eighteen $h$ before the end of the culture, BrdUrd $(50 \mu \mathrm{mol} / 1$ final concentration $)$ was added. At the end of the culture period, monolayers were washed twice with phosphate buffered saline-Dulbecco's modification of $E a$ gle's medium ( $\mathrm{pH} 7.4)$ and fixed with ethanol/acetic acid $95+5$ (by vol.). DNA was then denatured by incubating the cells for $45 \mathrm{~min}$ at $37^{\circ} \mathrm{C}$ with BrdUrd antibodies and nuclease. After washing 3 times with phosphate buffered saline (pH 7.4) cells were incubated with peroxidase-conjugated rabbit anti-mouseimmunoglobulins for $45 \mathrm{~min}$ at $37^{\circ} \mathrm{C}$. Cells were then washed again 3 times with phosphate buffered saline, and the nuclei, which had taken up BrdUrd, were stained with 3,3'-diaminobenzidine tetrahydrochloride as substrate and hydrogen peroxide $3 \%$, nickel chloride and cobalt chloride $30 \mathrm{~g} / 1$ in $\mathrm{H}_{2} \mathrm{O}$ as intensifier.

Determination of the synthesis of total glycosaminoglycans

The synthesis of sulphated glycosaminoglycans was determined from the incorporation of $\left[{ }^{35} \mathrm{~S}\right]$ sulphate $(18.5-22.2 \mathrm{TBq} / \mathrm{mol}$;
$740 \mathrm{MBq} / \mathrm{l}$ medium) during a labelling period of $24 \mathrm{~h}$ [details described elsewhere $(7,8,16)]$. Usually, the radionuclide was added after a medium change on the 3 rd day of primary culture. Cultures were stopped by removing the medium, washing the cell layer three times with phosphate buffered saline and freezing the cells. The cells were detached from the well by repeated $(3 \times)$ freezing and thawing and scraped off with a pipette tip. Less than $1 \%$ of the radioactivity remained in the well. Details of the procedure to determine the synthesis and secretion of sulphated glycosaminoglycans are described elsewhere (8). Briefly, glycosaminoglycans were isolated by binding to DEAESephacel (Pharmacia Fine Chemicals, Uppsala, Sweden), equilibrated with $0.3 \mathrm{~mol} / 1$ sodium acetate buffer $(\mathrm{pH} 6.6)$, extensively washed with the same buffer, and thereafter eluted with $2.2 \mathrm{~mol} / 1 \mathrm{NaCl}$. An aliquot of the eluate was mixed with Instagel (Packard Instruments Company, Downers Grove, Ill., USA) and counted for radioactivity. Glycosaminoglycan synthesis was expressed as radioactivity per mg DNA. In experiments using thrombocyte lysate to stimulate fat storing cells, glycosaminoglycans were measured separately in the medium and cell-layer of the cultures. Glycosaminoglycans of the cell layer were determined after proteolysis with papain (EC 3.4.22.2) as described previously (8).

\section{Results}

\section{Fat storing cell proliferation}

\section{Effect of thrombocyte lysate}

Proliferation of fat storing cells in foetal calf serumfree medium was stimulated by thrombocyte lysate in a dose dependent manner (fig. 2). $\left[{ }^{3} \mathrm{H}\right]$ thymidine incorporation and DNA content per culture were increased to a maximum of 8- and 2-fold, respectively, $48 \mathrm{~h}$ after the addition of $40 \mu \mathrm{l}(2.6 \mathrm{mg}$ protein) thrombocyte lysate to primary cultures of fat storing cells grown on $10 \mathrm{~cm}^{2}$ wells in $2 \mathrm{ml}$ Dulbecco's môd-

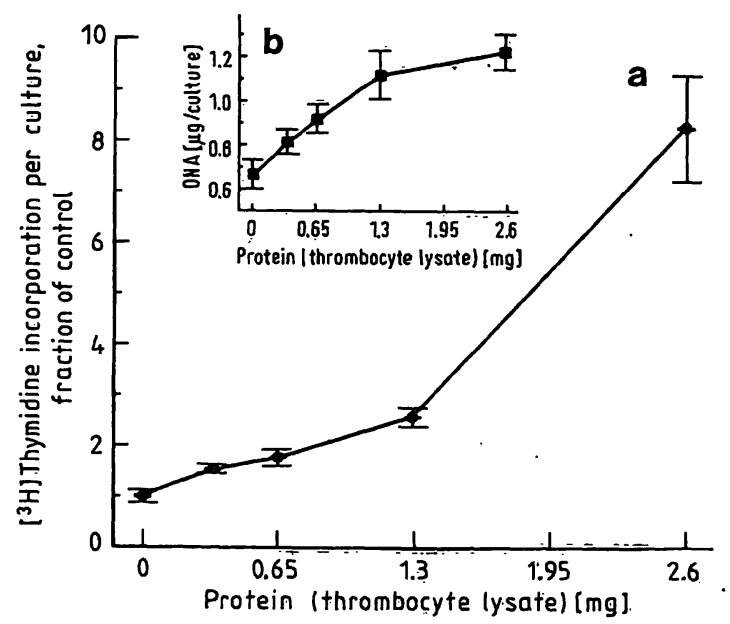

Fig. 2. Proliferation of fat storing cells measured by incorpóration of $\left[{ }^{3} \mathrm{H}\right]$ thymidine into DNA (a) and DNA content per culture (b). Cells were labelled with $\left[{ }^{3} \mathrm{H}\right]$ thymidine $(74 \mathrm{MBq} / \mathrm{l})$ for $24 \mathrm{~b}$ between the $3 \mathrm{rd}$ and 4 th culture day.

Thrombocyte lysate $(0.65-2.6 \mathrm{mg}$ protein/culture) was added on the second and third day after seeding. Cells were seeded at a density of $0.1 \times 10^{6} \mathrm{cells} / \mathrm{cm}^{2}$. Control culture received Dulbecco's modification of Eagle's medium without foetal calf serum. Mean values \pm SD of three independent experiments, each with $\mathrm{n}=\overline{4}$. 
ification of Eagle's medium without foetal calf serum. If fat storing cells were cultured in Dulbecco's modification of Eagle's medium containing a fraction of 0.1 foetal calf serum, the addition of thrombocyte lysate caused only a 2-fold stimulation of $\left[{ }^{3} \mathrm{H}\right]$ thymidine incorporation and it had no significant effect on the DNA content.

\section{Epidermal growth factor-stimulated fat storing cell pro- liferation}

Incubation of subconfluent rat fat storing cells with human epidermal growth factor in the presence of $5 \mathrm{ml} / 1$ foetal calf serum resulted in a dose-dependent stimulation of cell proliferation, as measured by $\left[{ }^{3} \mathrm{H}\right]$ thymidine incorporation (fig. 3a), DNA content per culture well (fig. $3 \mathrm{~b}$ ) and BrdUrd incorporation (tab. 1). Twenty $\mu \mathrm{g} / 1(3.3 \mathrm{nmol} / \mathrm{l})$ epidermal growth factor stimulated $\left[{ }^{3} \mathrm{H}\right]$ thymidine incorporation to a maximum of 3.5-fold, compared with controls. The $\mathrm{EC}_{50}$ for epidermal growth factor-stimulated $\left[{ }^{3} \mathrm{H}\right]$ thymidine incorporation was calculated to be about $8 \mu \mathrm{g} / 1(1.3 \mathrm{nmol} / \mathrm{l})$ using 7 concentrations of epidermal growth factor ranging from 5 to $1000 \mu \mathrm{g} / \mathrm{l}$. Fifty $\mu \mathrm{g} / \mathrm{l}$ epidermal growth factor produced maximal DNA synthesis (fig. $3 \mathrm{~b}$ ). In the presence of a higher foetal calf serum concentration $(100 \mathrm{ml} / \mathrm{l})$, epidermal growth factor failed to stimulate fat storing cell proliferation further (data not shown).

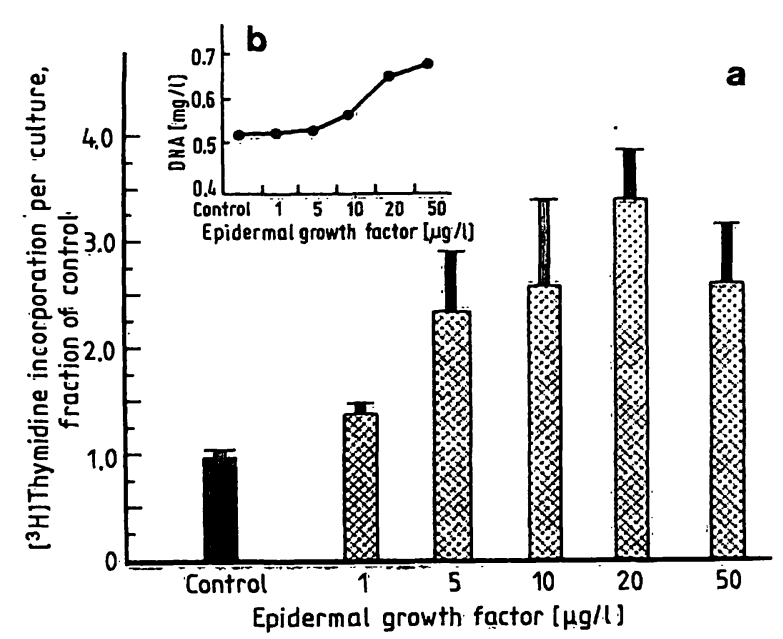

Fig. 3. Dose-dependent stimulation of fat storing cell proliferation measured by $\left[{ }^{3} \mathrm{H}\right]$ thymidine incorporation into DNA (a) and DNA content (b) by human epidermal growth factor. Cells were seeded at a density of 0.06 $\times 10^{6}$ cells $/ \mathrm{cm}^{2}$ in 6-well culture plates and grown in Dulbecco's modification of Eagle's medium containing a fraction of 0.005 foetal calf serum. Human epidermal growth factor $(1-50 \mu \mathrm{g} / \mathrm{l})$ was added on the second and third day after seeding.

Between the 3rd and 4th culture day cells were labelled with $\left[{ }^{3} \mathrm{H}\right]$ thymidine $74 \mathrm{MBq} / \mathrm{l}$ medium for $24 \mathrm{~h}$. Control culture was kept in Dulbecco's modification of Eagle's medium containing a fraction of 0.005 foetal calf serum. Mean values $\pm S D$ of three independent experiments, each with $n=4$.
Tab. 1. Effect of foetal calf serum (FCS) and epidermal growth factor (EGF) on fat storing cell proliferation.

Proliferation was measured by bromodeoxyuridine incorporation. Cells were seeded at a density of 0.06 $\times 10^{6}$ cells $/ \mathrm{cm}^{2}$ on glass cover slips in Dulbecco's modification of Eagle's medium (DMEM) containing a fraction of 0.1 foetal calf serum. After $24 \mathrm{~h}$ the fraction of foetal calf serum was reduced to 0.005 , and epidermal growth factor $(5 \mu \mathrm{g} / 1$ or $50 \mu \mathrm{g} / \mathrm{l})$ was added. Eighteen $h$ before the end of the culture cells were labelled with BrdUrd $\left(5 \times 10^{-5} \mathrm{~mol} / 1\right.$ final concentration). Nuclei which had taken up BrdUrd were stained by immunoperoxidase method using antibodies to BrdUrd. The control represents Dulbecco's modification of Eagle's medium containing a fraction of 0.005 foetal calf serum $(0.5 \%$ FCS $)$.

Immunoperoxidase (anti-BrdUrd)-stained nuclei (fraction of total cells)

\begin{tabular}{llll}
\hline $\begin{array}{l}\text { Control } \\
(0.005 \text { FCS })\end{array}$ & $\begin{array}{l}\text { DMEM }+ \\
0.10 \text { FCS }\end{array}$ & $\begin{array}{l}\text { EGF } \\
(5 \mu \mathrm{g} / \mathrm{l})\end{array}$ & $\begin{array}{l}\text { EGF } \\
(50 \mu \mathrm{g} / \mathrm{l})\end{array}$ \\
\hline 0.045 & 0.2 & 0.07 & 0.18 \\
\hline
\end{tabular}

Effect of transforming growth factor $\beta$ on fat storing cell proliferation and transformation

Transforming growth factor $\beta(0.025-2.5 \mu \mathrm{g} / \mathrm{l}$, $1-100 \mathrm{pmol} / \mathrm{l})$ inhibited, in a dose dependent manner, the proliferation of fat storing cells grown in Dulbecco's modification of Eagle's medium containing a fraction of 0.005 or 0.1 foetal calf serum (fig. 4). Since

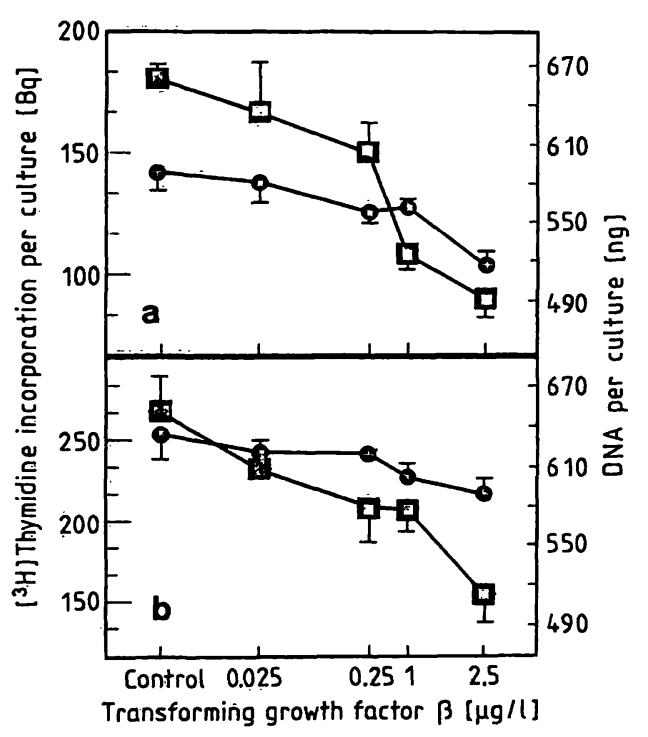

Fig. 4. Transforming growth factor $\beta$-induced dose-dependent inhibition of fat storing cell proliferation measured by $\left[{ }^{3} \mathrm{H}\right]$ thymidine incorporation into DNA $(\boldsymbol{\square}-\mathbf{v})$ and DNA content $(\bullet-\bullet)$. Cells were seeded at a density of $0.06 \times 10^{6} \mathrm{cells} / \mathrm{cm}^{2}$ in 6-well culture plates and grown in Dulbecco's modification of Eagle's medium containing a fraction of 0.005 foetal calf serum [a] or in Dulbecco's modification of Eagle's medium containing a fraction of 0.1 foetal calf serum [b]. Transforming growth factor $\beta$ was added on the 2 nd and 3 rd day after seeding. Between the 3rd and 4th culture day cells were exposed for $24 \mathrm{~h}$ to $\left[{ }^{3} \mathrm{H}\right.$ ] thymidine $74 \mathrm{MBq} / \mathrm{l}$ medium. Values represent mean \pm SD of 4 cultures. 


\section{Selenium in Medicine and Biology}

\section{Proceedings of the Second International Congress}

on Trace Elements in Medicine and Biology

March 1988 - Avoriaz, France

Editors Jean Nève, Alain Favier

1988. 17 x $24 \mathrm{~cm}$. XX, 428 pages. Numerous illustrations.

Hardcover DM 290,-; approx. US \$ 158.00 ISBN 3110117703

This book is a comprehensive and up-to-date review on the importance of selenium in human and animal nutrition. Starting from physiological aspects, it covers epidemiological and clinical data, giving detailed information on selenium requirements, supplementation and toxicity, and the methods for assessing selenium status. It includes contributions from famous experts and specialists in the field.

\section{From the Contents}

Selenium Intake, Metabolism and Homeostasis · Biological Functions of Selenium - Assessment of Selenium Status . Selenium in Human Diseases . Selenium Supplementation and Toxicity · Selenium in Animals · Author Index · Subject Index.

Price is subject to change without notice
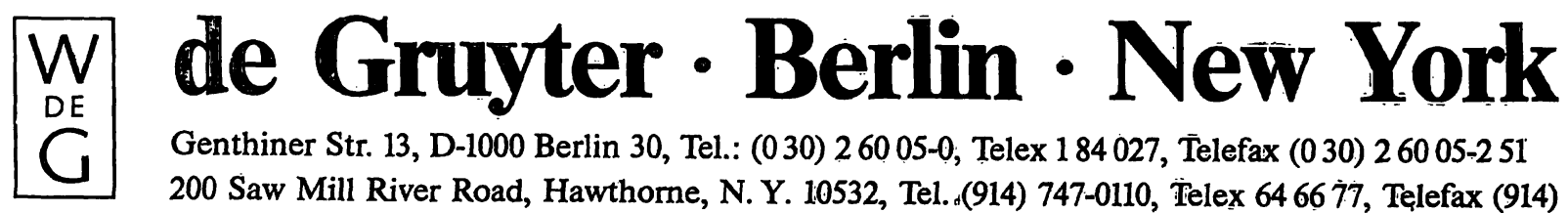

the culture period was only 4 days, the inhibition of $\left[{ }^{3} \mathrm{H}\right]$ thymidine incorporation was more pronounced (significant reduction with $10 \mathrm{pmol} / 1$ transforming growth factor $\beta$ ) than the decrease of the DNA content (significant reduction with $100 \mathrm{pmol} / \mathrm{l}$ transforming growth factor $\beta$ ). A higher transforming growth factor $\beta$ concentration $(6 \mu \mathrm{g} / \mathrm{l}, 240 \mathrm{pmol} / \mathrm{l})$, added on second and third day after seeding to primary cultures of rat fat storing cells (containing 0.005 foetal calf serum) inhibited basal $\left[{ }^{3} \mathrm{H}\right]$ thymidine incorporation by $90 \%$, while epidermal growth factor $(50 \mu \mathrm{g} / \mathrm{l}, 9.1$ $\mathrm{nmol} / \mathrm{l}$ ) stimulated cell proliferation by $92 \%$ (fig. 5). In a further experiment, fat storing cells were seeded at a density of 3000 cells $/ \mathrm{cm}^{2}$ and grown in Dulbecco's modification of Eagle's medium containing a fraction of 0.1 foetal calf serum in the presence or absence of $20 \mathrm{pmol} / \mathrm{l}$ transforming growth factor $\beta$. Cultures were stopped after $2,6,8,14,16$ and 18 days. Total cell numbers were counted using phase-contrast microscopy, and the fraction of desmin-positive cells was counted after immunoperoxidase staining for desmin. While inhibiting cell growth, transforming growth factor $\beta$ stimulated fat storing cell transformation to desmin-positive myofibroblast-like cells (fig. 6).

\section{Platelet derived growth factor-stimulated fat storing cell proliferation}

Platelet derived growth factor $(0.5 \mu \mathrm{g} / \mathrm{l}, 16.6 \mathrm{pmol} / \mathrm{l})$ was added, on the 2 nd day after seeding to primary cultures of fat storing cells grown in Dulbecco's modification of Eagle's medium without foetal calf serum. Under these conditions, platelet derived growth factor stimulated fat storing cells proliferation, as measured by $\left[{ }^{3} \mathrm{H}\right]$ thymidine incorporation, to a maximum of 2.1-fold compared with controls (tab. 2). The DNA content was increased by platelet derived growth factor $(2 \mu \mathrm{g} / \mathrm{l}, 66 \mathrm{pmol} / \mathrm{l})$ during $48 \mathrm{~h}$ of stimulation to 1.24 fold of control.

Synthesis and secretion of glycosaminoglycans by rat liver fat storing cells

\section{Stimulation by thrombocyte lysate}

Thrombocyte lysate caused a dose-dependent increase (up to 8-fold) of the incorporation of $\left[{ }^{35}\right.$ S]sulphate (per mg DNA) into the total proteoglycans of fat storing cells grown in Dulbecco's modification of $E a$ gle's medium without foetal calf serum (fig. 7). There was a preferential incorporation of $\left[{ }^{35}\right.$ S $]$ sulphate into the proteoglycans of the medium (about 11-fold), whereas proteoglycan radioactivity associated with the cell layer increased only 4-fold in the presence of lysate. When fat storing cells were cultured in Dul-

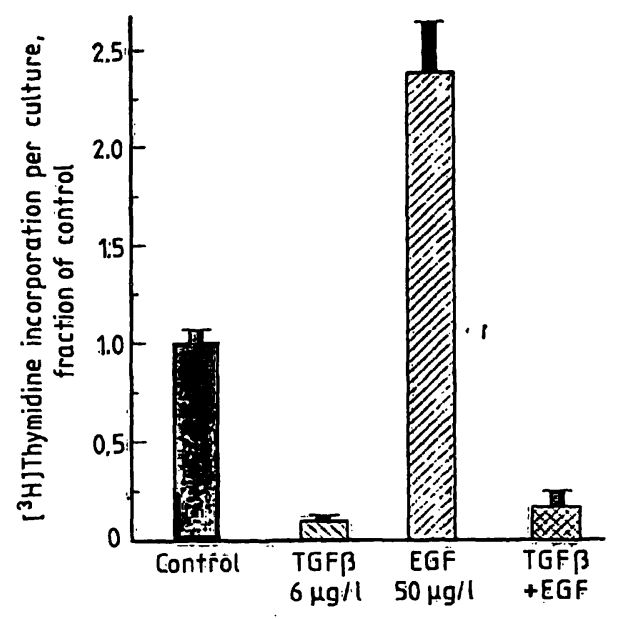

Fig. 5. Effect of transforming growth factor $\beta$ (TGF $\beta$ ) on epidermal growth factor (EGF) stimulated fat storing cell proliferation measured by $\left[{ }^{3} \mathrm{H}\right]$ thymidine incorporation. Cells were seeded at a density of $0.06 \times 10^{6}$ cells $/ \mathrm{cm}^{2}$ in 6 well culture plates and grown in Dulbecco's modification of Eagle's medium containing a fraction of 0.005 foetal calf serum. The controls were cultures kept in Dulbecco's modification of Eagle's medium containing a fraction of 0:005 foetal calf serum. Transforming growth factor $\beta$ was added simultanously with epidermal growth factor on the $2^{\text {nd }}$ and $3^{\text {rd }}$ day of culture. Cells were exposed for $24 \mathrm{~h}$ to $\left.{ }^{3} \mathrm{H}\right]$ thymidine $74 \mathrm{MBq} / \mathrm{l}$ medium.

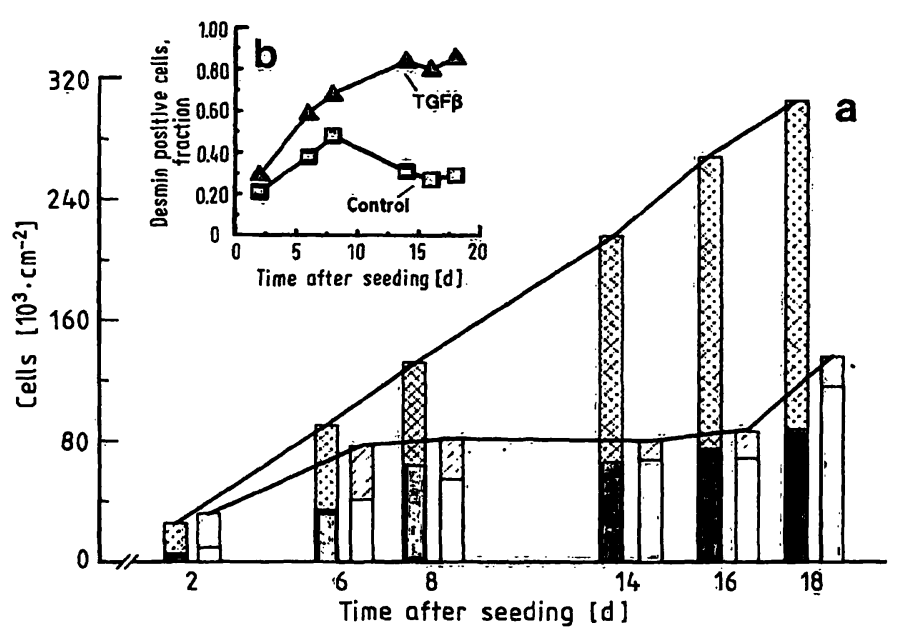

Fig. 6. Effect of transforming growth factor $\beta$ on fat storing cell growth and transformation to desmin-positive myofibroblast-like cells. Cells were seeded at a density of $3 \times 10^{3}$ cells $/ \mathrm{cm}^{2}$ and grown in Dulbecco's modification of Eagle's medium containing a fraction of 0.1 foetal calf serum in the presence [ $\square]$ and absence [ transforming growth factor $\beta$. Transforming growth fac= tor $\beta(20 \mathrm{pmol} / \mathrm{l})$ was added on the 1st, 5th, 7th, 13th, 15 th and 17th day of culture. Cultures were stopped on the $2 \mathrm{nd}, 6 \mathrm{th}, 8 \mathrm{th}, 14 \mathrm{th}, 16 \mathrm{th}$ and $18 \mathrm{th}$ day after seeding. In fig. $6 \mathrm{a}$ the black bars represent the number of desminpositive cells per $\mathrm{cm}^{2}$ in control, the grey bars represent the number of desmin-positive cells per $\mathrm{cm}^{2}$ in transforming growth factor $\beta$-treated cultures. The inset $b$ ). demonstrates the relative amount (fraction of total cells) of desmin-positive cells in control (i- $-\mathbf{E})$ and in transforming growth factor $\beta$-treated cultures $(\boldsymbol{\Delta}-\boldsymbol{\Delta})$. Total cell numbers were counted using phase-contrast microscopy (see fig. 1d) and desmin-positive cells were counted using light microscopy after immunoperoxidase staining for desmin (see fig. 1c). Mean values of 2 representative experiments are given. 
Tab. 2. Effect of platelet-derived growth factor on fat storing cell proliferation measured by $\left[{ }^{3} \mathrm{H}\right]$ thymidine incorporation.

Cells were seeded at a density of $0.1 \times 10^{6} \mathrm{cells} / \mathrm{cm}^{2}$ in 6-well culture plates and kept in Dulbecco's modification of Eagle's medium without foetal calf serum (FCS). Different concentrations of platelet derived growth factor $(0.25-5 \mu \mathrm{g} / \mathrm{l})$ were added on the 2 nd and 3 rd day of culture. Between the 3 rd and 4 th day cells were exposed for $24 \mathrm{~h}$ to $\left[{ }^{3} \mathrm{H}\right]$ thymidine $74 \mathrm{MBq} / \mathrm{l}$ medium. The mean values \pm SD of 4 cultures are shown.

$\left[{ }^{3} \mathrm{H}\right]$ thymidine incorporation (Bq/culture)

\begin{tabular}{lllll}
\hline Control & \multicolumn{3}{l}{ Platelet-derived growth factor $[\mu \mathrm{g} / \mathrm{l}]$} \\
\cline { 2 - 5 } without FCS & 0.25 & 0.5 & 2 & 5 \\
\hline $11.7 \pm 2.1$ & $20.6 \pm 4.8$ & $24.5 \pm 1.4$ & $18.3 \pm 2.3$ & $19.6 \pm 1.5$ \\
\hline
\end{tabular}

becco's modification of Eagle's medium containing a fraction of 0.1 foetal calf serum, the stimulatory effect of thrombocyte lysate on proteoglycan synthesis was much weaker (only 2-fold), suggesting that the enhancement of proteoglycan synthesis by foetal calf serum is largely due to platelet derived factors.

\section{Epidermal growth factor-stimulated glycosaminoglycan synthesis}

In the presence of $5 \mathrm{ml} / 1$ foetal calf serum, epidermal growth factor significantly stimulated proteoglycan synthesis, as measured by $\left[{ }^{35} \mathrm{~S}\right]$ sulphate incorporation in the proteoglycans of the medium. Epidermal growth factor $(3.3 \mathrm{nmol} / \mathrm{l}, 20 \mu \mathrm{g} / \mathrm{l})$, stimulated $\left[{ }^{35} \mathrm{~S}\right]$ sulphate incorporation per culture 2.3 -fold, and per mg DNA 1.6-fold, compared with controls.

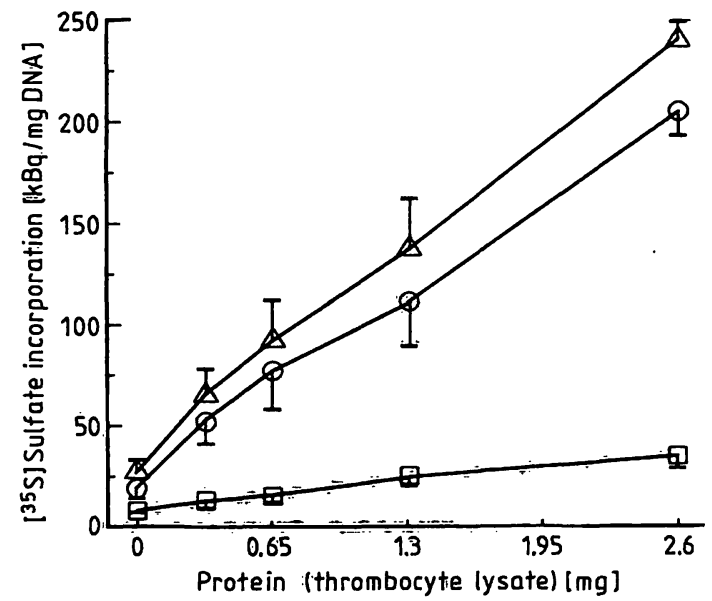

Fig. 7. Effect of thrombocyte lysate on $\left[{ }^{35}\right.$ Sjsulphate incorporation into glycosaminoglycans of cell layer and medium. Thrombocyte lysate $(0.65-2.6 \mathrm{mg}$ protein/culture) was added on the second and on the third day after seeding. Cells were seeded at a density of $0.1 \times 10^{6}$ cells $/ \mathrm{cm}^{2}$. Control cultures received Dulbecco's modification of Eagle's medium without foetal calf serum. After labelling for $24 \mathrm{~h}$ with ${ }^{35}$ S]sulphate $(740 \mathrm{MBq} / \mathrm{l}$ medium) glycosaminoglycans of cell layer $(\square-\square)$ and medium $(0-0)$ were analysed separately. Values are expressed as mean $\pm S D$ of three independent experiments, each with $n=4$ on the basis of DNA content. $\Delta-\Delta=$ total radioactivity.
Transforming growth factor $\beta$-stimulated glycosaminoglycan synthesis

Treatment of fat storing cells with transforming growth factor $\beta$ caused a dose-dependent enhanced radiosulphate incorporation into secreted (medium) glycosaminoglycans, with a maximal increase of about 2-fold at $2.5 \mu \mathrm{g} / 1$ in Dulbecco's modification of Eagle's medium containing $5 \mathrm{ml} / 1$ foetal calf serum (fig. 8a) and a maximal increase of about 1.7 fold at $1 \mu \mathrm{g}$ transforming growth factor $\beta$ per litre Dulbecco's modification of Eagle's medium containing $100 \mathrm{ml} / \mathrm{l}$ foetal calf serum (fig. $8 \mathrm{~b}$ ). In a preliminary experiment we found that in controls (Dulbecco's modification of Eagle's medium containing a fraction of 0.005 foetal calf serum) most $(75 \%)$ of the incorporated $\left[{ }^{35} \mathrm{~S}\right]$ sulphate was present in the dermatan-sulphate fraction, whereas heparan-sulphate contained $20 \%$ and chondroitin-sulphate only $5 \%$ of the radiosul-

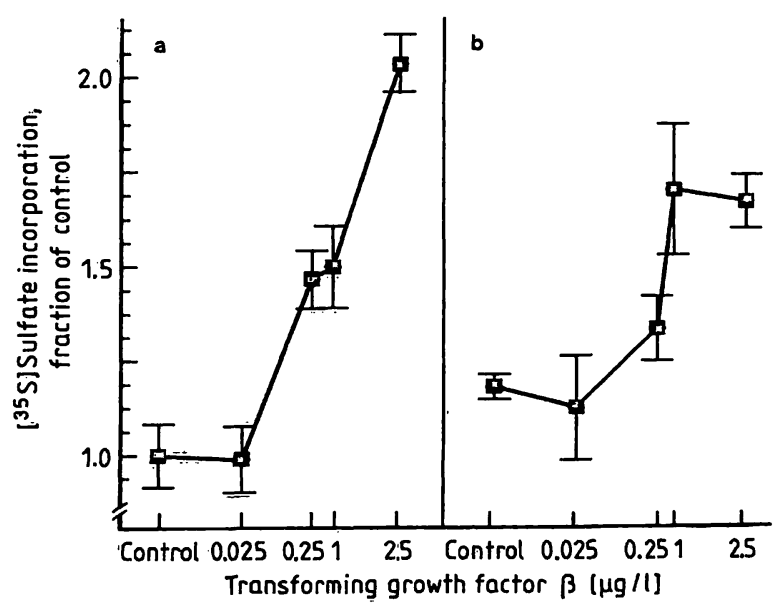

Fig. 8. Incorporation of $\left[{ }^{35} \mathrm{~S}\right]$ sulphate into medium glycosaminoglycans of fat storing cells grown in Dulbecco's modification of Eagle's medium containing a fraction of 0.005 (a) or 0.1 foetal calf serum (b), respectively. Cells were seeded at a density of $0.06 \times 10^{6}$ cells $/ \mathrm{cm}^{2}$ in 6well culture plates. Transforming growth factor $\beta$ was added on the 2 nd and 3 rd day after seeding. Between the $3 \mathrm{rd}$ and 4 th culture day cells were exposed for $24 \mathrm{~h}$ to $740 \mathrm{MBq}\left[{ }^{35} \mathrm{~S}\right]$ sulphate per litre medium. Values are expressed as mean \pm SD of 4 cultures on the basis of DNA. 
phate. Addition of transforming growth factor $\beta$ reduced the relative radiosulphate content of dermatansulphate from $75 \%$ to $62 \%$, and of heparan-sulphate from 20 to $10 \%$, but increased the relative $\left.{ }^{35} \mathrm{~S}\right]$ sulphate content of chondroitin-sulphate from 5 to $32 \%$. In contrast to newly synthesized and secreted dermatan-sulphate and heparan-sulphate, the absolute $\left[{ }^{35} \mathrm{~S}\right]$ sulphate incorporation, expressed as radiosulphate incorporation per mg DNA into chondroitin-sulphate, was also significantly stimulated by transforming growth factor $\beta$ (at $0.5 \mu \mathrm{g} / 1$ about 7 fold and at $2.0 \mu \mathrm{g} / 1$ more than 8 -fold) compared with controls.

\section{Effect of platelet derived growth factor on glycosami- noglycan synthesis}

Platelet derived growth factor $(0.25-5.0 \mu \mathrm{g} / \mathrm{l}, 8.3-$ $166 \mathrm{pmol} / \mathrm{l})$, added on the 2 nd day after seeding to primary cultures of fat storing cells grown in Dulbecco's modification of Eagle's medium without or with a fraction of 0.1 foetal calf serum, did not significantly increase the quantity of glycosaminoglycan synthesised per mg DNA.

\section{Discussion}

The ability of liver fat storing cells to proliferate strongly $(9,11,12)$, and to transform into myofibroblast-like cells $(4,11,13)$ which produce significant quantities of connective tissue components, is considered to be an important event in human and animal liver fibrogenesis $(1,5,7,10,16,17,18)$. Following all types of hepatic injury, an infiltration of the tissue with blood monocytes occurs, and this is paralleled by an enhanced proliferation of Kupffer cells (26) followed by a stimulated proliferation and transformation of fat storing cells. These observations and the electron microscopic demonstration of platelets together with infiltrated inflammatory cells in liver cell necrotic areas (20) support the hypothesis that factors released from these cells might directly promote the growth, transformation and extracellular matrix synthesis of fat storing cells.

Studies from others and from our laboratory support this hypothesis. It was shown recently that secretions of activated Kupffer cells and monocytes stimulate the proliferation/transformation of fat storing cells in culture $(9,12)$, as well as the synthesis of proteoglycans (16) and hyaluronic acid (10) by these cells. Comparing the magnitude of matrix proteoglycan and hyaluronate synthesis by fat storing cells with that of other liver cells, it was concluded that the fat storing cell is the most important cell in liver fibrogenesis (7). In cultures of fat storing cells labelled for $24 \mathrm{~h}$ with $\left[{ }^{3} \mathrm{H}\right]$ glucosamine or $\left[{ }^{35} \mathrm{~S}\right]$ sulphate, more than $70 \%$ of the labelled glycosaminoglycans are found in the extracellular medium (7). At present, the function of the sulphated glycosaminoglycans and other matrix elements secreted by fat storing cells is poorly understood. Several authors propose that the interaction of cells with the extracellular matrix influences cell behaviour, affecting cell adhesion and motility, growth and differentiation (for review see 1.c. (27)). Important new aspects of the putative functions of glycosaminoglycans are provided by observations showing that type III transforming growth factor $\beta$ receptor is a membrane heparan/chondroitin sulphate proteoglycan $(28,29)$ and that certain glycosaminoglycans act as reservoirs of growth factors (30). However, we have so far been unable to relate the high output of glycosaminoglycans by fat storing cells to specific autocrine or paracrine effects.

In the present study we demonstrated for the first time that platelets contain fibrogenic mediators which stimulate not only proliferation, but also the synthesis and secretion of glycosaminoglycans into the extracellular matrix by fat storing cells in primary culture. The main growth factors elaborated by platelets are transforming growth factor $\beta$ (platelets are the richest source of transforming growth factor $\beta 1$ (21)), platelet derived growth factor (31) and epidermal growth factor (23). The data presented in this study clearly demonstrate that primary cultures of rat fat storing cells grown in Dulbecco's modification of Eagle's medium containing a fraction of 0.005 foetal calf serum show a mitogenic response to human epidermal growth factor and platelet derived growth factor. Recently, we demonstrated that the epidermal growth factor-like transforming growth factor $\alpha$, which is produced by activated macrophages (19) and probably Kupffer cells (Bachem, unpublished data), binds to epidermal growth factor receptor on fat storing cells with a similar affinity to that of epidermal growth factor, and stimulates the proliferation of fat storing cells in culture (32). Epidermal growth factor and transforming growth factor $\alpha$ are equally potent in the stimulation of fat storing cell proliferation.

Transforming growth factor $\beta$, a $M_{\mathrm{r}}=25000$ disulphide-linked homodimer originally found in transformed fibroblasts $(21,22)$ belongs to a family of growth factors that regulate cell growth and differentiation (for review see 1.c. (33)). Transforming growth factor $\beta$ has been found to be both a stimulator $(33,34)$ and an inhibitor of cell growth $(28,33-$ 37) depending on the system studied. We showed that transforming growth factor $\beta$ strongly inhibited the proliferation of fat storing cells stimulated by foetal 
calf serum or epidermal growth factor. Similar results, i.e. a dose-dependent inhibition of the epidermal growth factor-stimulated proliferation, were obtained with cultured rat aortic smooth muscle cells (37). As proposed by Sporn et al. (38) and Roberts et al. (34) transforming growth factor $\beta$ stimulates or inhibits proliferation as a function of the entire set of growth factors present within the cell. Several in vitro studies indicate that transforming growth factor $\beta$ may control the effects of other polypeptide growth factors, such as platelet derived growth factor, epidermal growth factor/transforming growth factor $\alpha$, basic fibroblast growth factor and interleukin 2 , and that transforming growth factor $\beta$ can determine whether a cell responds in a positive or negative manner to such a growth factor (for review see 1.c. (38)). This action of transforming growth factor $\beta$ seems to be exerted via modulation of growth factor receptors, since it was shown recently that transforming growth factor $\beta$ inhibits epidermal growth factor/transforming growth factor $\alpha$ binding to the high affinity epidermal growth factor cell surface receptors on fibroblasts (39), and furthermore that the platelet derived growth factor-stimulated proliferation of bone marrow fibroblasts is also inhibited by interaction of transforming growth factor $\beta$ with platelet derived growth factor binding (35).

In cultured normal human dermal fibroblasts transforming growth factor $\beta$ stimulates the synthesis of types I and III collagens $(40,41)$ and fibronectin $(40$, $41,42)$. In endothelial cells, fibronectin synthesis is also stimulated by transforming growth factor $\beta$ (36). It is suggested that transforming growth factor $\beta$ may play a role in the normal regulation of extracellular matrix production in vivo, and may contribute to the development of pathological states of skin (41) and organ (43) fibrosis. The observation by Wiseman and coworkers (44), that transforming growth factor $\beta$ at very low concentrations $(16-100 \mathrm{ng} / \mathrm{l})$ may recruit monocytes from the circulation and activate them to express factors like tumour necrosis factor $\alpha$, may also by very relêvant to fibrogenesis. Transforming growth factor $\beta$ stimulates collagen synthesis in fat storing cells (45). We show here for the first time that transforming growth factor $\beta$ added to primary cul-

\section{References}

1. Gressner, A. M. (1986) Fibroplasie der Leber - aktueller Kenntnisstand molekularer und zellulärer Mechanismen. Med. Welt 37, 898-905.

2. Chojkier, M., Lyche, K. D. \& Pilip, M. (1988) Increased production of collagen in vivo by hepatocytes and nonparenchymal cells in rats with carbon tetrachloride-induced hepatic fibrosis. Hepatology 8, 808-814. tures of fat storing cells stimulates glycosaminoglycan synthesis and extracellular deposition of glycosaminoglycans. In bovine cartilage organ cultures, transforming growth factor $\beta$ was also shown to regulate the metabolism of glycosaminoglycans (46). Preliminary results showing that the synthesis of chondroitin sulphate is preferentially stimulated by transforming growth factor $\beta$ agree with observations made by others in mouse mammary epithelial cells (27).

Our results demonstrate that thrombocytes release fibrogenic mediators which stimulate fat storing cell proliferation/transformation and glycosaminoglycan synthesis by these cells. All three polypeptide growth factors studied (epidermal growth factor, platelet derived growth factor and transforming growth factor $\beta)$ are candidate mediators of platelet-derived fibrogenic activity in culture, and in vivo during hepatic injury. Others have shown that in acute $\mathrm{CCl}_{4}$ liver damage the level of transforming growth factor $\beta$ mRNA rises $24 \mathrm{~h}$ later and peaks at $48 \mathrm{~h}(47)$, and that transforming growth factor $\beta$ gene expression is significantly enhanced during active fibrogenesis associated with liver disease in man (48). Together with these observations, the results presented here indicate a central, fundamental role for transforming growth factor $\beta$ in hepatic fibrogenesis.

\section{Conclusion}

The observation that activated Kupffer cells, monocytes and thrombocytes, whose numbers are increased in areas of liver cell injury, stimulate fat storing cell proliferation/transformation and extracellular matrix synthesis, indicates the existence of cooperative interactions between different hepatic and extrahepatic cell types, mediated by paracrine mechanisms. These interactions seem to be important in liver fibrogenesis, a process in which transforming growth factor $\beta$ may play a central role.

\section{Acknowledgement}

We thank S. Schmittdiel and $L$. Scheckel for excellent technical assistance. The study was supported by grant Gr 463/8-1 from Deutsche Forschungsgemeinschaft.

3. Clement, B., Grimaud, J. A. \& Campion, J. (1986) Cell types involved in collagen and fibronectin production in normal and fibrotic human liver. Hepatology 6, 225-234.

4. De Leeuw, A. M., McCarthy, S. P. \& Geerts, A. (1984) Purified rat liver fat-storing cells in culture divide and contain collagen. Hepatology 4, 392-403. 
5. Friedman, S. L., Roll, F. J. \& Boyles, J. (1985) Hepatic lipocytes: the principal collagen-producing cells of normal rat liver. Proc. Natl. Acad. Sci. USA 82, 8681-8685.

6. Clement, B., Rescan, P.-Y., Baffet, G., Loreal, O., Lehry, D., Campion, J.-P. \& Guillouzo, A. (1988) Hepatocytes may produce laminin in fibrotic liver and in primary culture. Hepatology 8, 794-803.

7. Gressner, A. M. \& Schäfer, S. (1989) Comparison of sulphated glycosaminoglycan and hyaluronate synthesis and secretion in cultured hepatocytes, fat storing cells, and Kupffer cells. J. Clin. Chem. Clin. Biochem. 27, 141-149.

8. Schäfer, S., Zerbe, O. \& Gressner, A. M. (1987) The synthesis of proteoglycans in fat storing cells of rat liver. Hepatology 7, 680-687.

9. Zerbe, O. \& Gressner, A. M. (1988) Proliferation of fat storing cells is stimulated by secretion of Kupffer cells from normal and injured rat liver. Exp. Mol. Path. 49, 87-101.

10. Gressner, A. M. \& Haarmann, R. (1988) Hyluronic acid synthesis and secretion by rat liver fat storing cells. Biochem. Biophys. Res. Com. 151, 222-229.

11. Enzan \& H. (1985) Proliferation of Ito-cells in acute carbon tetrachloride liver injury. Acta Pathol. Jpn. 35, $1301-1308$.

12. Shiratori, Y., Geerts, A., Ichida, T., Kawase, T. \& Wisse E. (1986) Kupffer cells from $\mathrm{CCl}_{4}$-induced fibrotic livers stimulate proliferation of fat storing cells. J. Hepatol. 3, 294-303.

13. Mak, K., Leo, M. A. \& Lieber, C. S. (1984) Alcoholic liver injury in baboons: transformation of lipocytes to transitional cells. Gastroenterology 87, 188-200.

14. Ballardini, G.., Fallani, M., Biagini, G., Bianchi, F. B. \& Pisi, E. (1988) Desmin and actin in the identification of Ito cells and in monitoring their evolution to myofibroblasts in experimental liver fibrosis. Virchows Archiv B Cell Pathol. 56, 45-49.

15. Davis, B. H., Pratt, B. M. \& Madri, J. A. (1987) Retinol and extracellular collagen matrices modulate hepatic Ito cell collagen phenotype and cellular retinol binding protein levels. J. Biol. Chem. 262, 10280-10286.

16. Gressner, A. M. \& Zerbe, O. (1987) Kupffer cell-mediated induction of synthesis and secretion of proteoglycans by rat liver fat storing cells in culture. J. Hepatol. 5, 299310 .

17. McGee, JO'D \& Patrick, R. D. (1972) The role of perisinusoidal cells in hepatic fibrogenesis. Lab. Invest. 25, 429440.

18. Minato, Y., Hasumura, Y. \& Takeuchi, J. (1983) The role of fat-storing cells in Disse space fibrogenesis in alcoholic liver disease. Hepatology 3, 559-566.

19. Madtes, D. K., Raines, E. W., Sakariassen, K. S., Assoian, R. K., Sporn, M. B., Bell, G. I. \& Ross, R. (1988) Induction of transforming growth factor-alpha in activated human alveolar macrophages. Cell 53, 285-293.

20. Ogawa, K., Suzuki, J., Narasaki, M. \& Moro, M. (1985) Healing of focal injury in rat liver. Am J. Pathol. 119, 158167.

21. Assoian,R. K., Komoriya, A., Meyers, C. A., Miller, D. M. \& Sporn, M. B. (1983) Transforming growth factor- $\beta$ in human platelets: identification of a major storage site, purification and characterization. J. Biol. Chem. 258, $7155-7160$.

22. Assoian, R. K., Grotendorst, G. R., Miller, D. M. \& Sporn, M. B. (1984) Cellular transformation by coordinated action of three peptide growth factors from human platelets. Nature $309,804-806$.

23. Oka, Y. \& Orth, D. N. (1983) Human plasma epidermal growth factor/ $\beta$-urogastrone is associated with blood platelets. J. Clin. Invest. 72, 249-259.

24. Knook, D. L., Seffelaar, A. M. \& de Leeuw, A. M. (1982) Fat-storing cells of the rat liver. Their isolation and purification. Exp. Cell Res. 139, 468-471.

25. Labarca, C. \& Paigen, K. (1980) A simple, rapid, and sensitive DNA assay procedure. Anal. Biochem. 102, 344352.
26. Geerts, A., Schellinck, L., Bouwens, L. \& Wisse, E. (1988) Cell population knetics of Kupffer cells during the onset of fibrosis in rat liver by chronic carbon tetrachloride administration. J. Hepatol. 6, 50-56.

27. Rasmussen, S. \& Rapraeger, A. (1988) Altered structure of the hybrid cell surface proteoglycan of mammary epithelial cells in response to transforming growth factor $-\beta$. J. Cell Biol. 107, 1959-1967.

28. Cheifetz, S., Weatherbee, J. A., Tsang, M., Anderson, J. K., Mole, J. E., Lucas, R. \& Massague, J. (1987) The transforming growth factor- $\beta$ system, a complex pattern of cross-reactive ligands and receptors. Cell 48, 409-415.

29. Segarini, P. R. \& Seyedin, S. M. (1988) The high molecular weight receptor to transforming growth factor $\beta$ contains glycosaminoglycan chains. J. Biol. Chem. 263, 8366-8370.

30. Roberts, R., Gallagher, J., Spooner, E., Allen, T. D., Bloomfield, F. \& Dexter, T. M. (1988) Heparan sulphate bound growth factors: a mechanism for stromal cell mediated haemopoiesis. Nature 332, 376-378.

31. Stiles, C. D. (1983) The molecular biology of plateletderived growth factor. Cell 33, $653-655$.

32. Bachem, M. G., Riess, U. \& Gressner, A. M. (1989) Liver fat storing cell proliferation is stimulated by epidermal growth factor/transforming growth factor alpha and inhib= ited by transforming growth factor beta. Biochem. Biophys. Res. Commun. (in press).

33. Massague, J. (1987) The transforming growth factor- $\beta$ family of growth and differentiation factors. Cell 49, 437-438.

34. Roberts, A. B., Anzano, M. A., Wakefield, L. M., Roche, N. S., Stern, D. F. \& Sporn, M. B. (1985) Type $\beta$ transforming growth factor: a bifunctional regulator of cellular growth. Proc. Natl. Acad. Sci. USA 82, 119-123.

35. Bryckaert, M. C., Lindroth, M., Lönn, A., Tobelem, G. \& Wasteson, A. (1988) Transforming growth factor (TGFß) decreases the proliferation of human bone marrow fibroblasts by inhibiting the platelet-derived growth factor (PDGF) binding. Exp. Cell Res. 179, 311-321.

36. Müller, G., Behrens, J., Nussbaumer, U., Böblen, P. \& Birchmeier, W. (1987) Inhibitory action of transforming growth factor $\beta$ on endothelial cells. Proc. Natl. Acad. Sci. USA $84,5600-5604$.

37. Ouchi, Y., Hirosumi, J., Watanabe, M., Hattori, A., Nakamura, T. \& Orimo, H. (1988) Inhibitory effect of transforming growth factor- $\beta$ on epidermal growth factor-induced proliferation of cultured rat aortic smooth muscle cells. Biochem. Biophys. Res. Commun. 157, 301-307.

38. Sporn, M. B. \& Roberts, A. B. (1986) Peptide Growth factors and inflammation, tissue repair, and cancer. J. Clin. Invest. 78, 329-332.

39. Massague, J. (1985) Transforming growth factor-beta modulates the high-affinity receptors for epidermal growth factor and transforming growth factor-alpha. J. Cell. Biol. $100,1508-1514$

40. Ignotz, R. A. \& Massague, J. (1986) Transforming growth factor- $\beta$ stimulates the expression of fibronectin and collagen and their incorporation into the extracellular matrix. J. Biol. Chem. 261, 4337-4345.

41. Varga, J., Rosenbloom, J. \& Jimenez, S. A. (1987) Transforming growth factor beta (TGF beta) causes a persistent increase in steady-state amounts of type $\widetilde{\mathrm{I}}$ and type III collagen and fibronectin $\mathrm{mRN}$.As in normal human dermal fibroblasts. Biochem. J. 247, 597-604.

42. Balza, E., Borsi, L., Allemanni, G. \& Zardi, L. (1988) Transforming growth factor beta regulates the levels of different fibronectin isoforms in normal human cultured fibroblasts. FEBS Lett. 228, 42-44.

43. Roberts, A. B., Sporn, M. C., Assoian, R. K., Smith, J. M., Roche, N. S., Wakefield, L. M., Heine, L. A., Falanga, V., Kehrl, J. H. \& Fauci, A. S. (1986) Transforming growth factor type $\beta$ : rapid induction of fibrosis and angiogenesis in vivo and stimulation of collagen formation in vitro. Proc. Natl. Acad. Sci. USA 83, 4167-4171. 
44. Wiseman, D. M., Polverini, P. J., Kamp, D. W. \& Leibovich, S. J. (1988) Transforming growth factor-beta (TGF $\beta$ ) is chemotactic for human monocytes and induces their expression of angiogenic activity. Biochem. Biophys. Res. Commun. 157, 793-800.

45. Matsuoka, M., Pham, N. T. \& Tsukamoto, H. (1988) Release of transforming growth factor beta1 (TGF beta1) like activity by Kupffer cells in alcoholic liver fibrogenesis and its stimulation of lipocyte collagen formation. Hepatology 8, 1231 (Abstr. 52).
46. Morales, T. I. \& Roberts, A. B. (1988) Transforming growth factor $\beta$ regulates the metabolism of proteoglycans in bovine cartilage organ cultures. J. Biol. Chem. 263, 1282812831.

47. Czaja, K. C., Flanders, L., Biempica, M. A., Zern, M. A. \& Weiner, F. R. (1988) Differential expression of tumor necrosis factor-alpha and transforming growth factor- $\beta 1$ in acute liver injury. Hepatology 8, 1234 (Abstr. 63).

48. Annoni, G., Czaja, M. J., Weiner, F. R. \& Zern, M. A. (1988) Increased transforming growth factor- $\beta 1$ (TGF- $\beta 1$ ) gene expression in human liver disease. Hepatology 8,1227 (Abstr. 36).

Dr. Dr. M. G. Bachem

Abt. f. Klin. Chemie u. Zentrallaboratorium Philipps Universität

Baldingerstraße

D-3550 Marburg 
